\title{
Guru Profesional Di Era Digital
}

\author{
Ana suheri ${ }^{1}, \operatorname{Rosmawiah}^{1}$, Effrata $^{1}$, Yossita Wisman $^{1 *}$ \\ ${ }^{1}$ Universitas Palangka Raya, Indonesia \\ e-mail:yossitayosie@yahoo.com
}

Diterima: 13 Nopember 2020; Disetujui: 30 November 2020; Diterbitkan: 2 Desember 2020

\begin{abstract}
ABSTRAK
Guru merupakan komponen pendidikan yang utama. Berbagai komponen pendidikan lainnya, seperti kurikulum, sarana prasarana, dan lainnya tidak akan berarti apa-apa, jika tidak ada guru yang menerapkan dan menggunakannya. Karena demikian pentingnya seorang guru, telah disepakati bahwa guru merupakan tenaga profesional yang membutuhkan berbagai persyaratan yang menjamin profesinya itu dapat dilaksanakan dengan baik. Persyaratan profesi tersebut terus berkembang sesuai dengan tuntutan zaman. Dalam era digital seperti yang terjadi saat ini, guru profesional kembali dipertanyatakan persyaratannya. Selain persyaratan-persyaratan yang telah dimiliki sebelumnya, ia perlu ditambah dengan persyaratan lainnya yang sesuai. Dengan merujuk berbagai literatur yang otoritatif dalam jumlah yang memadai, serta disajikan secara deskriptif analitis, tulisan ini lebih lanjut memfokuskan pembahasannya pada persyaratan guru profesional yang dibutuhkan di era digital.
\end{abstract}

Kata kunci : Guru, Profesional,Era Digital.

\section{PENDAHULUAN}

Guru adalah pendidik profesional dengan utama mendidik, membimbing, mengarahkan, melatih, menilai dan mengevaluasi peserta didik pada pendidikan anak usia dini, jalur pendidikan formal, pendidikan dasar dan pendidikan menengah. Sebagai tenaga profesional guru wajib memiliki kualifikasi akademik, kompetensi, sertifikat pendidik, sehat jasmani dan rohani, serta memiliki kemampuan untuk mewujudkan tujuan pendidikan nasional. Kompetensi tersebut meliputi kompetensi pedagogik, kompetensi kepribadian, kompetensi sosial dan kompetensi profesional. Kompetensi pedagogik meliputi 18 butir kemampuan, yaitu:Pemahaman wwasan atau landasan pendidikan, pemahaman terhadap peserta didik, pengembangan kurikulum atau silabus, perencangan pembelajaran, pelaksanaan pembelajaran yang mendidik dan dialogis, pemanfaatan teknologi pembelajaran, evauasi hasil belajar, pengembangan peserta didik untuk mengaktualisasikan potensi yang dimulikinya. Sedangkan kompetensi kepribadian meliputi 13 butir kompetensi, yaitu: beriman dan betakwa, berakhlak mulia, arif dan bijaksana, demokratis, mantap, berwibawa, stabil, dewasa, jujur, sportif, menjadi teladan bagi peserta didik dan masyarakat, mengembangkan diri secara 
mandiri dan berkelanjutan. Selanjutnya kompetensi sosial meliputi 13 kemampuan, yaitu:berkomunikasi secara lisan, tulisan dan/atau isyarat secara santun, menggunakan teknologi komunikasi dan informasi secara fungsional, bergaul secara efektif dengan peserta didik, sesama pendidik, tenaga kependidikan, pimpinan satuan pendidik, orang tua atau wali peserta didik, bergaul secara santun dengan masyarakat sekitar dengan mengindahkan norma serta sistem nilai yang berlaku dan menerapkan prinsip persaudaraan sejati dan semangat kebersamaan. Sedangkan kompetensi profesional meliputi penguasaan materi pelajaran secara luas dan mendalam, konsep dan metode disiplin keilmuan, teknologi atau seni yang relevant.

Selanjutnya Soetjipto menjelaskan pengertian profesi yang ditandai oleh ciri-ciri sebagai berikut: (a)Melayani masyarakat, merupakan karier yang akan dilaksanakan sepanjang hayat (tidak berganti-ganti pekerjaan); ((b)Memerlukan bidang ilmu dan keterampilan tertentu di luar jangkauan khalayak ramai (tidak setiap orang dapat melakukannya); (c)Menggunakan hasil penelitian dan aplikasi dari teori ke praktek (teori baru dikembangkan dari hasil penelitian); (d)Memerlukan latihan khusus dengan waktu yang panjang; (e)Terkendali berdasarkan lisensi baku dan atau mempunyai persyaratan masuk (untuk menduduki jabatan tersebut memerlukan izin tertentu atau ada persyaratan husus yang ditentukan untuk dapat mendudukinya); (f)Otonomi dalam membuat keputusan tentang ruang lingkup kerja tertentu (tidak diatur oleh orang luar); (g)Menerima tanggung jawab terhadap keputusan ang diambil dan untuk kerja yang ditampilkan yang berhubungan dengan layanan yang diberikan (langsung bertanggung jawab terhadap apa yang diputuskannya, tidak dopindahkan ke atas atasan atau instansi yang lebih tinggi; (h)Mempunyai komitmen terhadap jabatan dan klien, dengan penekanan terhadap layanan yang aan diberikan; (i)Menggunakan administrasi untuk memudahkan profesinya, relatif bebas dari supervisi dalam jabatannya; (j)Mempunyai organisasi yang diatur oleh anggota profesi sendiri; (k)Mempunyai asosiasi profesi dan atau kelompok "elit" untuk mengetahui dan mengakui keberhasilan anggotanya; (l)Mempunyia kode etik untuk mengerjakan hal-hal yang meragukan atau menyangsikan yang berhubungan dengan layanan yang diberikan; (m)Mempunyai kadar kepercayaan yang tinggi dari publik dan kepercayaan diri setiap anggotanya; dan (n)Mempunyai status sosial dan ekonomi yang tinggi.

Kriteria guru profesional tersebut telah dimuat dalam Pasal 1, 2 dan 3 Undang-undang Nomor 74 Tahun 2008 tentang Guru. Ini berarti bahwa secara nasional kriteria guru profesional tersebut telah disepakati. Kesepakan kriteria guru profesional tersebut sudah merupakan hasil kajian yang mendalam oleh tim perancang undang-undang tersebut yang terdiri dari para pakar, pejabat dan praktisi pendidikan. Kajian terhadap berbagai literatur yang oritatif dan kredibel dalam rangka menetapkan kriteria guru profesional tersebut diyakini dan dipastikan sudah dilakukan. Demikian pula pada saat uji publik dalam kaitan 
dengan kemungkinan penerapan kriteria tersebut bisa diterapkan sudah dibicakan secara mendalam.

Saat ini masyarakat termasuk para guru sudah memasuki era digital, yaitu suatu era yang sudah melampaui era teknologi komputer. Menurut data yang diketahui, bahwa jumlah penjualan komputer saat ini sudah cenderung menurun dan terkalahkan oleh jumlah penjualan teknologi digital handphone. Hal ini antara lain disebabkan oleh adanya sejumlah kelebihan teknologi digital dibandingkan komputer atau laptop. Dari segi isi atau programnya, teknologi digital handphone lebih lengkap dibandingkan komputer; dari segi pelacakan dan sistem kerjanya dalam mencari data nampak lebih cepat, dari segi harganya lebih terjangkau; dari segi bentuk dan besarannya lebih simpel dan bisa disimpan disaku baju, dari segi ongkos operasinalnya lebih ringan dan dari segi mobilitasnya lebih fleksibel. Dengan berbagai kondisi objektif, sudah dapat dipastikan, bahwa jumlah masyarakat yang menggunakan teknologi digital akan jauh lebih banyak, hingga ke peloksok pedesaan dibandingkan dengan penggunaan teknologi komputer. Tidak hanya itu, ekspansi dan daya inovasi teknologi digital handhone jauh juga lebih cepat. Ia benar-benar mengikuti selera masyarakat, bahkan jauh melebihi selera dan imajinasi masyarakat. Teknologi digital telah menawarkan beragam komunikasi, yakni selain dalam komunikasi dengan voice dan sms, juga bisa melalui face books, wash up, yo tobe, astagram, yo tube. Selain dapat mengirim data, teknologi digital juga dapat menyimpan data hampir tanpa batas, menyediakan data melalui Google; bisa mendengarkan musik, bacaan ayat-ayat al-Qur'an, do'a, gruping tadarusan dan tahfidz al-Qur'an, kirima pesan puisi, doa, taushiyah, mengecek tabungan di bank, transaksi, dan lain sebagainya. Masyarakat saat ini telah memasui era digital.

\section{PEMBAHASAN}

\section{Karakter Teknologi Digital}

Guru profesional yang ditandai oleh empat macam kompetensi (paedagogik, kepribadian, sosial dan profesinal) sebagaimana tersebut di atas kembali dipertanyakan. Yakni apakah kriteria kompetensi tersebut masih memadai, atau sudah tidak memadai lagi, sehingga perlu adanya penyempurnaan. Dilihat dari segi waktu dirumuskannya kriteria tersebut, yakni sekitar tahun 2008 yang berarti baru berumur 9 tahun, nampak bahwa rumusan kriteria tersebut disusun pada masa yang sudah masuk ke era digital. Dugaan ini benar adanya, karena di dalam kriteria kompetensi pedadogik dan kompetensi sosial sebagaimana tersebut di atas sudah memasukan unsur teknologi digital. Pada kompetensi pedagogik sudah dimasukkan keharusan pemanfaatan teknologi pembelajaran; dan pada kompetensi sosial sudah dimasukan menggunakan teknologi komunikasi dan informasi secara fungsional. Namun demikian, kriteria kompetensi pedagogik dan sosial tersebut masih perlu disempurnakan karena beberapa alasan. Pertama, jarak waktu sembilan tahun yakni tahun 2008 ketika Undang-undang Nomor 14 Tahun 
2008 sampai dengan sekarang untuk melihat perkembangan teknologi digital sudah cukup lama, karena ekspansi dan ekselerasi inovasi teknologi digital pada setiap tahun selalu mengalami perkembangan yang luar biasa. Seseorang yang hidupnya selalu mengikuti perkembangan teknologi digital akan tidak pernah berhenti untuk menyediakan waktu, pikiran dan dana untuk mengadakan, mencari dan memburunya, karena tanpa itu, kelengkapan sarana dan prasarana kehidupannya akan terasa kurang, dan social psychologinya akan terasa terganggu, ia merasa dirinya sebagai orang yang kurang up to date. Selanjutnya, walaupun kriteria guru profesional tersebut di atas sudah bernuansa teknologi digital, yakni menggunakan teknologi komunikasi dan informasi secara fungsional serta pemanfaatan teknologi pembelajaran, namun kriteria tersebut belum secara eksplisit menyebutkan teknologi digital.

Teknologi secara harfiah berarti ilmu tentang teknik. Ia merupakan aplikasi dari sintesis sains atau natural sciencies dengan teknik. Sains adalah hasil penelitian empirik berupa observasi dan eksperimen yang dirumuskan dengan bantuan akal pikiran. Sedangkan teknologi adalah aplikasi atau cara-cara penerapan sains dalam realitas kehidupan melalui eksperimen dan kegiatan piloting selama bertahun-tahun. Dengan demikian teknologi adalah hasil peneletian terapan. Penelitian model seperti biaya memerlukan ketekunan, waktu dan biaya yang tinggi. Oleh sebab itu yang akan menguasai perkembangan teknologi adalah bangsa-bangsa yang memiliki etos kerja keilmuan yang tinggi serta anggaran yang besar. Itulah sebabnya, negara-negara yang melahirkan dan mengembangkan teknologi adalah negara-negara yang sudah maju. Amerika, Jepang, Korea, Finlandia, dan China, misalnya termasuk negara yang melahirkan berbagai teknologi digital yang sangat dinamis, karena bangsa-bangsa tersebut di samping memiliki modal, juga memiliki modal etos kerja dan ketekunan di atas rata-rata bangsa lain.

Teknologi memang buatan manusia, namun ketika teknologi tersebut lahir ia memiliki sifat, karakter, kepribadian, jati diri atau akhlaknya sendiri. Sifat-sifat tersebut pada mulanya dilahirkan dan dilekatkan oleh manusia pada teknologi tersebut. Dengan kata lain, pada teknologi tersebut terdapat sebagian dari hasil akal pikiran manusia. Sebagai hasil dari akal pikiran manusia seharusnya teknologi tunduk pada kemauan manusia. Namun dalam realitanya tidak demikian. Teknologi memiliki sifat, karakter, kepribadian, jati diri atau akhlaknya sendiri. Jika seseorang ingin memanfaatkan teknologi tersebut ia harus mengikuti sifat, karakter, kepribadian, jati diri atau akhlaknya sendiri. Tanpa mau mengikuti sifat, karakter, kepribadian, jati diri atau akhlaknya, maka manusia tidak akan dapat memanfaatkan teknologi tersebut. Oleh karena itu orang yang mau memanfaatkan teknologi, harus terlebih dahulu diperkenalkan dan dibiasakan menggunakan teknologi tersebut, melalui kegiatan pelatihan, magang, learning by doing, dan sebagainya. 
Teknologi memiliki karakter dan budayanya sendiri. Sebuah cangkul misalnya, adalah teknologi tradisional yang amat sederhana. Namun ketika seseorang akan menggunakannya ia harus mengikuti logikanya, misalnya cara memegangnya, cara mengayunkannya, posisi orang yang menggunakannya, arah yang dikenai sasaran dan sebagainya. Tanpa mau mengikuti logikanya, maka cangkul yang dibuatnya itu akan menjadi "senjata makan tuan". Ia tidak akan menghasilkan tanah yang gembur, melainkan kaki yang baba belur. Demikian pula teknologi digital, walaupun ia buatan manusia, namun ia memiliki logikanya sendiri. Manusia yang menggunakannya harus mengikuti logikanya itu. Di antara logika teknologi digital adalah: (1)Sistemik. Yakni bahwa ia dirancang dalam sebuah sistem yang canggih, yaitu suatu keadaan di mana antara satu bagian dengan bagian lainnya saling berkaitan dan berurutan. Satu sistem akan tampil dan berfungsi sebagaimana mestinya, apabila satu sistem yang lain yang merupakan patner yang merupakan pre-requisitenya sudah ada. Karena sistem tersebut selalu di up date, maka seseorang yang akan menggunakannya harus terus meng update kemampuan memahami perkembangan sistem tersebut. Sebagai suatu sistem, teknologi digital tak ubahnya seperti anggota tubuh manusia yang antara satu dan lainnya saling berkaitan. Ketika ada bagian anggota badan yang terluka, maka yang merasakannya bukan hanya bagian anggota yang terkena luka itu saja, melainkan sekujur tubuh ikut merasakannya. Oleh karena itu, jika ada salah satu elemen yang rusak, terutama pada elemen yang pokok, maka teknologi digital tersebut tidak akan dapat bekerja, atau akan mati. Jika dalam tubuh manusia, komponen yang paling urgen adalah jantung, maka dalam teknologi digital adalah chip-nya, jika chipnya dicabut, maka teknologi digital akan berhenti bekerja. Agar seseorang dapat menggunakan teknologi digital secara benar, maka ia harus mempelajari sistemnya, sebagaimana diatur dalam manual books yang dikeluarkan oleh perusahaan atau industri yang mengeluarkan teknologi digital tersebut. (2)Netral. Pada dasarnya teknologi digital atau teknologi apapun bersifat netral. Ia tidak baik atau tidak buruk oleh dirinya sendiri, melainkan amat bergantung pada manusia yang merancang dan menggunakannya. Jika orang yang merancangnya memasukan sistem, program atau menu yang tidak baik, kotor, seperti gambar, video atau film forno, atau tindakan kekerasan, maka teknologi tersebut menjadi kotor, dan orang yang menggunakannya akan terkena pengaruh buruk, misalnya ia terdorong untuk melakukan perbuatan buruk tersebut, seperti melakukan kegiatan pesta seks, pesta minuman keras, tindakan kriminal, dan lain sebagainya. Sebaliknya, jika orang yang merancangnya memasukan sistem, program atau menu yang baik, seperti menu bacaan atau hafalan al-Qur'an, bacaan do'a, taushiyah, kegiatan sosial keagamaan dan gambar-gambar yang membangkitkan spiritualitas, maka orang yang menggunakannya akan terdorong untuk melakukan hal-hal yang baik. Dengan karakter teknologi digital yang demikian, maka penggunaan teknologi digital tergantung pada manusia yang merancang dan menggunakannya. Dalam kaitan ini, maka pemberian wawasan 
yang benar dan komprehensif tentang teknologi digital, serta landasan moral dan etik yang berbasis pada nilai-nilai agama, budaya, tradisi, dan kearifan lokal, nasional dan internasional perlu dimiliki oleh setiap orang yang menggunakannya. (3)Terbatas. Walaupun teknologi digital tersebut sudah semakin canggih dan telah dapat melayani kebutuhan manusia terutama dalam membangun komunikasi dan melakukan tukar menukar informasi, namun ia tetap saja terbatas. Ia tidak dapat berbuat sendiri, tidak bisa menentukan dirinya sendiri, ia tidak memiliki perasaan, keinginan, dan kehendak atas dirinya sendiri. Karena itu, sehebat apapun kemampuan teknologi digital, ia tidak dapat sepenuhnya menggantikan peran manusia. Teknologi sehebat apapun tidak akan dimintakan pertanggung jawaban; yang dimintakan tanggung jawab adalah orang yang menggunakannya.

\section{Teknologi Digital}

Sebagaimana telah disebutkan di atas, bahwa sebagai salah satu syarat guru profesional di era digital, adalah seorang guru yang selain memiliki kompetensi pedagogik, kepribadian, sosial dan profesional sebagaimana telah disebutkan di atas, juga harus memiliki wawasan, ketertarikan, kepedulian, kepekaan, kesukaan, serta kemampuan dan keterampilan dalam menggunakannya. Penggunaan teknologi digital ini demikian penting, karena beberapa pertimbangan sebagai berikut.

Pertama, bahwa mutu pendidikan di Indonesia, mau jauh tertinggal dibandingkan dengan mutu pendidikan di negara-negara lain. Di antara sebab ketertinggalnya ini karena rendahnya mutu tenaga guru, dan di antara sebab rendahnya mutu guru dalam hal wawasan, ketertarikan, kepedulian, kepekaan, kesukaan, serta kemampuan dan keterampilan dalam menggunakan teknologi. Beberapa negara, seperti Mynmar, Singapura, Vietnam, Filipina, Brunnei Darussalam, Thailand, Malaysia. Pada tahun 2003, atau 14 tahun yang lalu, Mynmar telah menetapkan penggunaan teknologi komunikasi dan informasi sebagai bagian dari 10 butir kebijakan pada pendidikan dasar. Sementara itu pada jenjang perguruan tinggi ada 36 program yang terfokus pada 6 kawasan, yaitu pengembangan sumber daya manusia, penggunaan teknologi, penelitian, masyarakat belajar sepanjang hayat, peningkatan mutu pendidikan dan pelestarian nilai-nilai dan identitas nasional. Demikian pula Singapura, sejak tahun 1997 telah menetapkan untuk membawa bangsanya menjadi bangsa yang berfikir dan memeliki warga negara yang siap serta mampu memberikan kontribusi bagi perkembangan dan kesejahteraan Singapura. Untuk itu teknologi komunikasi dan informasi, dengan penekanan pada komputer, tidak lagi pada radio dan TV, digunakan secara luas untuk mengembangkan kemampuan komunikasi dan belajar mandiri. Program-program berbasis komputer telah digunakan di sekolah untuk mempersiapkan siswa-siswa menghadapi tantangan abad 21. (Arief S.Sadiman: 85 dan 88). 
Kedua, bahwa teknologi digital memiliki berbagai fungsi yang relevan untuk diintegrasikan ke dalam kegiatan belajar mengajar. Sudarno Sudirdjo dan Eveline Siregar dalam Mozaik Teknologi Pendidikan (2004:9-12), misalnya menyebutkan 8 fungsi dari teknologi pembelajaran termasuk digital yaitu (1)memberikan pengetahuan tentang tujuan belajar; (2)memotivasi siswa; (3)menyajikan informasi; (4)merangsang diskusi, (5)mengarahkan kegiatan siswa; (6)melaksanakan latihan dan ulangan, (7)menguatkan belajar, dan (8)memberikan pengalaman simulasi. Sedangkan Damian Ryan dalam Understanding Digital Marketing (1997:151) mengatakan: Social media is the umbrella term for web based software and servixe that allow used to come together online and exchange, discuss, communicates and participate in any form of social interaction. That interaction cam encompass text, audio, images, video, and other media, individually or in any combanion. It can involved the generation of $n w$ contents, the recommendation of and sharing of existing content; reviewing and rating products, sevices and brands discussing the ht topics of the day; pursuing habbies, internets, and passions, sharing experience and expertise. In factm almost anything, that law be distributed and shared through digitak channels in fair game. Artinya: Media sosial adalah sebuah istilah yang memayungi web yang berbasis pada perangkat lunak dan pelayanan yang membolehkan pada pengguna untuk datang bersama-sama pada online dan tukar menukar informasi, diskusi, komunikasi dan partisipasi dalam berbagai bentuknya yang terdapat dalam interaksi sosial. Interaksi tersebut, dapat mendorong penggunaan bahan bacaan, pendengaran, khayalan, vedio dan media lainnya, secara individual atau gabungan. Teknologi juga dapat menjangkau generasai pada isi yang baru, saran dan masukan untuk saling tukar menukar informasi, menilai dan menata ulang suatu produk, pelayanan dan pendelegasian, mendiskusikan tentang berbagai topik harian, meningkatkan gememaran, daya tarik dan passion, tukar menukar pengalaman dan keahlian. Faktanya, semua hal tersebut dapat didistribusikan and dikerjasamakan melalui jaringan teknologi digital sebagai permainan yang adil.

Ketiga, bahwa teknologi digital merupakan sebuah proses revolusi yang mau tidak mau harus dijalani. Alvin Toffler misalnya membagi masyarakat ke dalam masyarakat agraris (agricultural society), masyarakat industri (industrial sociey) dan masyarakat informasi (informatical society).Masyarakat agraris ditandai oleh pola hidup yang berorientasi pada masa lalu, kurang menghargai waktu, bekerja tanpa perencanaan, komunikasi secara face to face, ukuran kekayaan pada tanah dan hewan ternak, dan menggunakan teknologi sederhana yang bisa didaur ulang (re-cycle) dengan alam secara cepat. Sedangkan masyarakat industri, ditandai oleh pola hidup yang berorientasi pada masa depan, sangat menghargai waktu, bekerja dengan perencanaan, komunikasi jarak jauh, ukuran kekayaan pada penguasaan mesin industri, dan menggunakan teknologi canggih yang sulit didaur ulang. Sementara itu, masyarakat informasi, selain ditandai oleh ciri-ciri masyarakat industri juga ditandai oleh penggunaan teknologi 
penerima, penyimpan, pengolah dan pengirim data yang canggih (komputer dan laptop, dan kini teknologi digital yang dapat memainkan peran melebihi kemampuan komputer dan laptop dalam berbagai aspeknya. Dunia pendidikan di Indonesia saat ini, nampaknya harus melayani ketiga model masyarakat tersebut. Melayani model masyarakat agraris lebih mudah dibandingkan menghadapi masyarakat industri, dan menghadapi masyarakat informasi lebih sulit dibandingkan dengan menghadapi masyarakat industri. Hadirnya ketiga model masyarakat ini, akan merubah paradigma yang mendasari berbagai komponen pendidikan. Konsep belajar mengajar pada masyarakat informasi bukan lagi dengan cara transfer of knowedge atau transfer of skill, melainkan lebih ditekankan pada menggerakan, memotivasi, menjembatani, memfasilitasi, agar peserta didik tergerak melakukan berbagai kegiatan guna memperoleh pengetahuan yang dikehendakinya yang selanjutnya diberikan penguatan, pengayaan, atau perbaikan oleh guru. Demikian pula paradigma yang mendasari konsep kurikulum dan silabus, sumber bahan ajar, lingkungan dan evaluasi pendidikan juga mengalami perubahan, dan semua harus berbasis sesuai keadaan masyarakat. Jika selama ini para guru terbiasa bertugas melaksanakan pekerjaan profesionalnya dengan paradigma pendidikan yang berbasis masyarakat agraris dan industri, maka saat ini, para guru harus melaksanakan pekerjaan profesionalnya dengan paradigma pendidikan yang berbasis informasi digital. Merubah paradigma dari agraris ke industri, dan dari industri ke informasi, bukanlah pekerjaan yang mudah karena selain membutuhkan perubahan sikap mental, mindset, pola pikir, paradigma, juga membutuhkan sarana prasarana, biaya dan lain sebagainya. Dalam konteks ini, para guru harus siap untuk berani keluar dari kebiasaan lama (out of the box).

Keempat, bahwa dilihat dari segi fungsinya, teknologi digital selain dapat bekerja lebih cepat, juga dapat menjangkau wilayah yang lebih cepat. Dengan menggunakan teknologi digital, batas-batas teritorial sudah tidak menjadi penghalang lagi. Batas-batas wilayah walaupun fisiknya tetap ada, namun fungsinya sudah tidak dapat menghalangi lagi (borderless). Dalam kaitan ini tepat sekali apa yang dikatakan..... sebagai berikut: Because new technologyes become generallu avilable more quickly, tool has bocomr even more of a critical element in strategy. Nothing stay proprietary for long. And no rol played can master every thing. Thus operating globally means oportunity with panters and that in turn means a fuitther spread of technology. (Karena teknologi baru secara umum menyediakan percepatan lebih banyak, maka waktu menjadi demikian elemen yang paling kritis dalam menentukan strategi. Tidak ada tempat tinggal yang dapat disediakan untuk sepanjang zaman. Tidak ada seorang pemain yang dapat menadi guru bagi semua hal. Dengan demikian, pelaksanaan secara global berarti bekerjasama dengan patner dan hal itu sudah demikian pada tahap selanjutnya menyebarkan teknologi. 
Dalam rangka pemerataan pendidikan yang merupakan salah satu program yang penting dari pemerintah, karena merupakan amanat Undang-undang Dasar 1945, maka penggunaan teknologi digital menjadi sangat penting. Hal yang demikian, disebabkan karena Indonesia adalah termasuk salah satu negara terbesar di dunia yang ditandai oleh karakter wilayahnya yang bersifat kepulauan yang antara satu dan lainnya berjauhan, sulit ditempuh dengan jalan darat. Problema teritori dalam kaitannya dengan pemerataan pendidikan ini akan dapat diatasi dengan penggunaan teknologi digital. Untuk itu berbagai sarana prasarana dan infra struktur yang memungkinkan jaringan teknologi digital tersebut dapat ditransmisikan, seperi jaringan listrik, tiang pemancar, kabe jaringan dan lainnya harus disiapkan. Beberapa daerah yang terpencil, seperti wilayah Indonesia Indonesia Timur, Kalimantan, Sulawesi dan lainnya perlu dibantu penyediaan sarana prasana dan infra struktur tersebut dalam kurun waktu yang pasti dan dilaksanakan secara terencana.

Kelima, dewasa ini sumber belajar makin banyak dan varitif, baik dari segi materinya, jenis maupun bentuknya. Berbagai sumber belajar tersebut tidak mungkin lagi dapat dikuasai oleh seorang yang waktu, tenaga, dan lainnya terbatas. Sumber dan baha ajar saat ini sudah tersebar di berbagai media, seperi google, face book, you tobe, email, faximile, sms, vido call dan lain sebagainya. Perkembangan sumber belajar yang demikian itu telah merubah paradigma pembelajaran dari yang bersifat manual atau face to face menjadi bersifat digital dan terjadi secara inter-connecting. Terkait dengan ini, menarik sekali apa yang dikatakan oleh Damain Ryan: Social media website come in a wide variety of "flavours", which are all broadly based around the premise of personal interaction; creating, exchanging and sharing contents, rating and discussing its relative merits as a community. The contents can be links to other website, new articles or blog post, photopraphs, audio, video, questions posed by other userts, anything, in fact, that can be distributed in digital form.[5] (Media sosial website sudah sangat berkembang luas yang semakin luas jangkauannya guna mendukung interaksi antara manusia, menciptakan, tukar menukar and sharing pendapat, penyusunan dan diskusi tentang keunggiulan yang relatif pada sebuah masyarakat. Isi tersebut dapat berhubungan dengan website yang lain, artikel yang baru atau post blog, potografi, audio, video, pertanyaan yang diterapkan oleh pengguna, apapun dalam faktanya dapat dibagikan melalui bentuk digital.

Keenam, bahwa penggunaan teknologi digital dalam bentuk online misalnya sudah merambah ke dalam kegiatan sosial, ekonomi, politik, budaya dan lain sebagainya. Penggerakan masa dan pembentuk opini publik yang biasanya dilakukan dengan cara kampanye yang berhadapan langsung (face to face) dengan kelompok sasaran misalnya sudah dapat digantikan melalui blog, situs, web, face book, what's up dan sebagainya. Selanjutnya mempengaruhi orang untuk membeli sebuah jasa atau produk dalam bentuk makanan, minuman, pakaian, 
peralatan kosmetik, peralatan teknologi, dan lainnya sudah dapat dilakukan melalui teknologi digital dalam bentuk on line. Seseorang yang membutuhkan jasa antara jemput dengan kendaraan roda dua, roda empat, kereta api, pesawat udara dan lainnya sudah dapat diorder melalui jaringan on line. Sikap dan budaya masyarakat yang sudah demikian familiar atau akrab dengan teknologi digital dalam bentuk on line adalah merupakan momentum yang tepat untuk dimanfaatan. Dengan memperhatikan dan mempertimbangkan beberapa kondisi objektif dan gagasan-gagasan inovatif dan akseleratif dalam bidang pelayann pendidikan yang berbasis digital technology, maka mau tidak mau seorang guru profesional harus menguasai teknologi digital tersebut dan menggunakannya dalam kegiatan pembelajaran.

\section{Guru Profesional dan Edukasi}

Dari paparan tersebut di atas, sudah dapat diketahui, bahwa guru profesional di era digital adalah guru yang dalam melaksanakan tugas-tugasnya sebagaimana disebutkan di atas berbasis pada penggunaan jaringan yang didukung teknologi digital. Kegiatan yang demikian itu selanjutnya dikenal dengan nama EdukasiNet. Yaitu sutus pembelajaran yang menyediakan bahan belajar berbasis web yang bersifat interaktif serta menyediakan fasilitas komunikasi antara pengajar dengan peserta didik, antara peserta didik, dan peserta ddik dengan sumber belajar lain. Penggunaan teknologi digital tidak hanya dalam kegiatan belajar mengajar saja, melainkan juga dalam melaksanakan tugas-tugas lainnya, seperti dalam pengelolaan administrasi pendidikan, pemberian tugas-tugas, pelaksanaan evaluasi dan lain sebagainya. Selain itu, guru yang dibutuhkan di era digital adalah guru yang memiliki kemahiran dalam menilai penggunaan teknologi yang edukatif dan non eduktif. Guru hendaknya terus mengevaluasi kemampuan siswa yang dibutuhkan untuk bersaing dalam ekonomi global. Ia juga harus menjadi pembelajar seumur hidup dan harus bersedia untuk belajar tidak hanya dari rekanrekan mereka, tetapi juga dari siswa mereka juga.

Lebih lanjut Prof.Dr. H. Arief Rahman, MP, menyebutkan, bahwa guru profesional di era digital adalah guru yang mahir dan gandrung akan teknologi informasi dan berbagai aplikasi komputer. Bahkan informasi yang diakses oleh para generasi digital ini tak terbatas pada informasi yang berkaitan dengan pendidikan saja, melainkan informasi yang berkaitan dengan kepentingan pribadi mereka. Generasi tersebut memiliki beberapa ciri yang dapat terlihat dalam kehidupan sehari-harinya. Ciri-cirinya menurut Arief, sebagakmana dikutip Muhammad Khairil, adalah seperti sangat suka dan sering berkomunikasi dengan semua kalangan, khususnya lewat jejaring sosial, seperti facebook, twiter, atau sms. Melalui media tersebut mereka lebih bebas berekpresi, baik apa yang mereka rasakan maupun pikirkan secara spontan. Kelebihan dari generasi tersebut memiliki daya toleransi yang lebih besar terhadap perbedaan kultur dan sangat peduli pada lingkungan, serta mampu melakukan berbagai aktivitas dalam waktu 
bersamaan, seperti membaca buku sembari mendengarkan musik. Sedangkan kelemahannya ialah selalu menginginkan segala sesuatu secara cepat, tanpa bertele-tele ataupun berbelit-belit. Selain utu, generasi tersebut cenderung kurang dalam komunikasi secara verbal, cenderung egosentris dan individualis, cenderung ingin serba instan, tidak sabaran, dan tidak menghargai proses. Berbagai kegiatan ini selengkapnya dapat dikemukakan sebagai berikut.

\section{Kegiatan Belajar Mengajar}

Strategi pembelajaran yang meliputi pengajaran, diskusi, membaca, penugasan, presentasi dan evaluasi, secara umum keterlaksanaannya tergantung dari satu atau lebih dari tiga mode dasar dialog/komunikasi dilakukan dengan cara dialog/komunikasi antara guru dengan siswa; dialog/komunukasi antara siswa dengan sumber belajar, dan dialog/komunikasi di antara siswa. Apabila ketiga aspek tersebut bisa diselenggarakan dengan komposisi yang serasi, maka diharapkan akan terjadi proses pembelajaran yang optimal. Para pakar pendidikan menyatakan bahwa keberhasilan pencapaian tjuan dari pembelajaran sangat ditentukan oleh keseimbangan antara ketiga aspek tersebut (Pelikan, 1992). Selain itu dinyatakan pula bahwa perancangan suatu pembelajaran dengan mengutamakan keseimbangan antara ketiga dialog/komunikasi tersebut sangat penting pada lingkungan pembelajaran berbasis Web. Dari sejumlah studi yang telah dilakukan, menunjukkan bahwa internet memang bisa dipergunakan sebagai media pembelajaran, seperti studi yang dilakukan oleh Center for Applied Special Technology (CAST) pada tahun 1969 yang dilakukan terhadap sekitar 500 murid kelas 5 dan 6 sekolah dasar. Ke-500 murid tersebut dimasukan dalam dua kelompok, yaitu kelompok eksperimen yang dalam kegiatan belajarnya dilengkapi dengan akses ke internet dan kelompok kontrol. Setelah dua bulan menunjukkan bahwa kelompok eksperimen mendapat nilai yang lebih tinggi berdasarkan hasil tes akhir.

\section{Pengelolaan Administrasi Pembelajaran}

Pengelolaan administrasi pembelajaran dapat diartikan suatu upaya melakukan penataan, pencatatan, penyimpanan dan pelayanan terhadap berbagai hal yang berkaitan dengan kegiatan pembelajaran, seperti daftar hadir peserta didik, kurikulum dan silabus, daftar nilai harian, mingguan, bulanan dan smesteran, soal ujian, bahan-bahan pengajaran, dan lain sebagainya. Semua hal tersebut dapat disimpan dengan menggunakan teknologi digital, dan pada bagianbagian tertentu dapat diakses oleh peserta didik.

\section{Penugasan-penugasan}

Penugasan dapat diartikan segala sesuatu yang dirancang dan disiapkan oleh guru untuk dikerjakan oleh peserta didik. Tugas-tugas tersebut di antaranya mengumpulkan tulisan dari surat kabar dan majalah, mengunjungi perpustakaan, laboratorium, workshop dan sebagainya untuk melakukan sebuah kegiatan 
pembelajaran seperti menjawab masalah yang sudah ditetapkan, membuktikan sebuah teori atau hipotesa dan sebagainya. Pelaksanaan tugas tersebut kemudian dilaporkan kepada guru. Pelaporan tersebut dapat menggunakan information technology. Dalam kaitan ini, seorang guru selain menguasai bahn yang akan ditugaskan juga harus menguasai teknologi informasi.

\section{Penyampaian Informasi}

Salah satu kompetensi seorang guru profesional adalah memiliki kompetensi sosial, yakni kemampuan membangun komunikasi dan silaturahmi dengan peserta didik, orang tua peserta didik, kepala sekolah, sesama guru, dan masyarakat pada umumnya. Dalam komunikasi tersebut antara satu dan lainnya saling memberikan informasi, sehingga berbagai ide, pesan dan gagasan secara bersama-sama. Dalam penyampaian informasi tersebut dapat menggunakan peralatan teknologi digital. Dalam hubungan ini, seorang guru juga dapat menyampaikan bahan-bahan yang harus dibaca atau dikerjakan.

\section{Pelaksanaan Evaluasi}

Pelaksanaan evaluasi dengan berbagai macamnya termasuk salah satu tugas seorang guru profesional. Evaluasi dilaksanakan secara objektif, transfaran, adil, dan akuntable. Guna mencapai tujuan tersebut, maka diperlukan ketelitian dan pengawasan yang ketat, sehingga tidak terjadi penyontrekan, plagiasi dan sebagainya. Melalui sistem digital, diharapkan dapat diciptakan sebuah sistem yang dengan mudah dapat mengetahui, apakah jawaban dalam evaluasi yang diberikan para peserta didik asli karyanya sendiri, atau hasil nyontek atau plagiasi.

\section{Tools yang Tepat}

Guru di era digital harus memiliki kualitas yang mumpuni agar dapat menjadi seorang pendidik yag inspiratif. Namun, kualifikasi guru yang demikian itu tidak akan berjalan jika tidak didampingi oleh tools atau piranti yang tepat. Agar dapat mendidik peserta didik di era digital dibutuhkan tools berbasis inernet yang dapat dengan mudah diakses dan digunakan oleh mereka. Tentunya akses ini tak hanya berisikan basis informasi dan materi perihal ilmu yang tengah dipelajarinya. Selain itu, harus pula memiliki fitur lain yang pasinya membuat pesrta didik lebih leluasa bereksperimen untuk menguasai suatu cabang ilmu tertentu. Oleh sebab itu, kehadiran Quipper di Indonesia sebagai platform pendidikan digital dirasa tepat sebagai tools bagi guru untuk menjangkau peserta didik yang termasuk generasi digital. Dengan visi "distributors of wisdom, Quipper sejatinya memiliki tujuan untuk meminimalisir kesenjangan pendidikan yang terjadi hampir di berbagai belahan dunia melalui kanal-kanal digitalnya. Dua produk Quipper, yakni Quipper School dan Quipper Video, memungkinkan guru dan peserta didik dapat berinteraksi dan melakukan kegiatan belajar mengajar secara online. Keberadaan Quipper itu, sejalan dengan metode pengajaran di era 
digital, yakni terpusat pada peserta didik. Dalam kaitan ini, Quipper menyediakan soal-soal dan materi pengajaran.

Namun demikian, digital technologi tersebut tidak sepenuhnya dapat menggantikan peran guru. Guru bukan hanya mengajar yang mentransfer ilmu pengetahuan dan keterampilan kepada peserta didik, melainkan memberikan bimbingan, latihan, teladan, pembiasaan, dan kasih sayang dan cinta kasih serta menyentuh hati nurani dan pribadinya dalam rangka pembentukan karakter, mental dan moral peserta didik. Prof. Dr. Arief Rachman mengatakan, bahwa guru tetap yang utama membimbing siswa saat belajar. Teknologi hanya sarana atau alat yang tergantung kepada tujuan dari orang yang menggunakannya. Dengan demikian ada sebagian tugas yang dikerjakan guru, dan sebagian tugas lainnya didelegasikan kepada peralatan teknologi digital.

\section{KESIMPULAN}

Berdasarkan uraian dan analisa sebagaimana tersebut di atas, dapat dikemukaan catatan penutup sebagai berikut.

Pertama, guru profesional di era digital pada dasarnya adalah guru yang memiliki kompetensi pedagogik, kepribadian, sosial dan profesional. Namun pada pelaksanaan keempat kompetensi tersebut memerlukan dukungan teknologi digital dengan berbagai macam dan ragamnya. Dengan demikian, guru profesional di era digital adalah guru yang dalam melaksanakan tugas keprofesionalannya berbasis pada teknologi digital.

Kedua, penggunaan teknologi digital dapat dilakukan oleh guru pada kegiatan belajar mengajar, pelayanan administrasi, penugasan dan evaluasi. Untuk itu, pengusaan guru terhadap sistem, website dan tool harus disediakan secara lengkap dan berkelanjutan.

Ketiga, keberadaan teknologi digital sebagian dapat menggantikan atau membantu peran guru terutama pada aspek pengajaran yang bertumpu pada transfer of knowledge and tekhnology and skill, namun tidak dapat menggantikan peran guru sebagai pendidik, yang bertugas membentuk karakter, mental, kepribadian, sikap dan tabi'at melalui penanaman nilai-nilai luhur, yang berbasis pada agama dan nilai-nilai budaya luhur yang dilakukan dengan cinta kasih, melalui keteladanan, bimbingan, latihan, pembiasaan, dan sebagainya.

\section{DAFTAR PUSTAKA}

Asmawi, Jamal Ma'ruf, Great Teacher, (Yogyakarta:Diva Press, 2016), cet. I.

Bahri, Saiful, Djamhari, Guru dan Anak Didik dalam Interaksi Edukatif suatu Pendekatan Teoritis Psikologis, (Yogyakarta:Rineka Cipta, 2005), cet. III.

Bilali, Abdul Hamid, Profil Murabi Ideal, (Jakarta:An Nadwah, 1426 H./2005), cet. I.

Falah, Saiful, Guru ada Ustadz adalah Guru Catatan Seorang Pendidik dengan Lebih dari 10.000 Anak Didik, (Jakarta:Republika, 2012), cet. I. 
Kasyadi, Suparlan, dkk, Strategi Belajar dan Pembelajaran, (Tangerang:Pustaka Mandiri, 2014), cet. I.

Miarso, Yusuf, Menyemai Benih Teknologi Pendidikan, (Jakarta:Prenada Media Kerjasama dengan Pusat Komunikasi dan Informasi Pendidikan Postekom, DIKNAS, 2004), cet. I.

Manis, Hilda, Learning is Easy, Tip dan Prosedur Praktis agar Belajar jadi Asyik, Edukatif dan Menyenangkan, (Jakarta:Kompas Gramedia, 2010).

Miller, John P., dkk., Holistic Learning and Spirituality in Education, (New York: State University of New York Press, 2005).

Mulyoto, Strategi Pembelajaran di Era Kurikulum Tahun 2013, (Jakarat:Prestasi Pustaka, 2013), cet. I.

Ohmae, Kenichi, The Borderless Wolrd, Power and Strategy in the Interlinked Economy, (USA:Haprer Business A Division of Harper Collins Publishers, 1990).

Prawiradilaga, Dewi Salma dan Eveline Siregar, Mozak Teknologi Pendidikan, (Jakarta: Prenada Media dan Universitas Negeri Jakarta, 2004), cet. I.

Ryan, Damian, Understanding Digital Marketing, Marketing Strategies for Engaging The Digita Generation, (London, Philadelphia New Delhi: Kogan Page, 2014), First Edition.

Sadiman, Arief S., SEAMEO, "Pendayagunaan Teknologi Pendidikan di Negara Tetangga," dalam Yusuf Hadimiarso, Menyemai Benih Teknologi Pendidikan, (Jakarta:Prenada Media Kerjasama dengan Pusat Komunikasi dan Informasi Pendidikan Postekom, DIKNAS, 2004), cet. I.

Sinamo, Jansen, Guru Etos Indonesia, 8 Etos Keguruan, (Jakarta:Darma Mahardika, 2010), Cet. II.

Suetjipto, dan Raflis Kosasi, Profesi Keguruan, (Jakarta:Rineka Cipta, 2009), cet. I.

Toffler, Alvin Author of Future Schock, The Third Wave, (New York: William Morrow and Company, Inc, 1980)

Al-Wa'iy, Taufik Yusuf, Kekuatan Sang Murabbi, Menggali Energi Intelektual dan Personal Murabbi, (Jakarta:Al-'Itishom Cahaya Umat, 2003), cet. I.

Undang-undang Nomor 74 Tahun 2008 tentang Guru, (Jakarta:Kementerian Pendidikan dan Kebudayaan, 2008), cet. I.

Yusuf, Taufik, al-Wa'yi, Kekuatan Sang Murabbi, Menggali Energi Intelektual dan Rasional Murabbi, (Jakarta:al-'Itishom Cahaya Umat, 2006). 